\title{
Hubungan Antara Beban Tugas Dengan Efikasi Diri dan Kepuasan Kerja Pensyarah di Kolej Vokasional
}

\author{
Zuhaili Mohd Arshad, Ramlee Mustapha* \\ Fakulti Pendidikan Teknikal dan Vokasional, Universiti Pendidikan Sultan Idris, 35900 Tanjung Malim, Malaysia \\ *Corresponding author: dr.ramlee@fptv.upsi.edu.my
}

\begin{abstract}
Previous studies have shown that self-efficacy and job satisfaction become critical factors that motivate educators to become productive in their career, and promote organizational excellence in education. However, changes in education policies resulting the teachers to have high workload in the workplace. This is a correlational research, and carried out to identify the relationship between workload and self-efficacy and job satisfaction among lecturers at vocational colleges. A total of 373 questionnaires containing 60 items were collected from the lecturers from 15 vocational colleges which were selected using cluster random sampling technique. Data was analyzed using SPSS version 22. Data were analyzed using t-test, ANOVA and Pearson-r correlation. Results showed that the workload of the lecturers at vocational colleges are at a high level (mean $=3.73)$, self-efficacy remained at a high level $($ mean $=3.81)$ and job satisfaction lecturer at the medium level $($ mean $=3.57)$. Based on the analysis, it was found that the workload significantly correlated with self-efficacy and job satisfaction in a negative direction and the strength of the relationship is at the low level. Self-efficacy was found to have a significant relationship with job satisfaction and the strength of the relationship is at the medium level.
\end{abstract}

Keywords: Work load; self efficacy; job satisfaction; technical and vocational education

\begin{abstract}
Abstrak
Kajian lepas menunjukkan efikasi diri dan kepuasan kerja menjadi faktor kritikal menjadikan pendidik bermotivasi dan produktif dalam kerjaya, seterusnya menjadi pemangkin kepada kecemerlangan organisasi pendidikan. Namun, perubahan dalam dasar pendidikan negara dan kelemahan dalam penetapan tugas menyebabkan pendidik memikul beban tugas yang tinggi di tempat kerja. Kajian ini berbentuk korelasi, dan dijalankan bagi mengenalpasti hubungan antara beban tugas dengan efikasi diri dan kepuasan kerja dalam kalangan pensyarah di kolej vokasional. Sebanyak 373 soal selidik yang mengandungi 60 item dikumpulkan daripada pensyarah daripada 15 buah kolej vokasional yang dipilih menggunakan teknik persampelan rawak kluster. Data dianalisis menggunakan perisian SPSS versi 22. Data dianalisis menggunakan ujian-t, ANOVA dan korelasi Pearson-r. Dapatan kajian mendapati beban tugas pensyarah di kolej vokasional berada pada tahap yang tinggi $(\mathrm{min}=3.73)$, efikasi diri berada pada tahap yang tinggi $(\min =3.81)$ dan kepuasan kerja pensyarah pada tahap yang sederhana $(\mathrm{min}=3.57)$. Berdasarkan analisis korelasi, didapati beban tugas mempunyai hubungan yang signifikan dengan efikasi diri dan kepuasan kerja dalam arah negatif dan kekuatan hubungan yang lemah. Efikasi diri pula didapati mempunyai hubungan signifikan dengan kepuasan kerja dengan kekuatan hubungan yang sederhana.
\end{abstract}

Kata kunci: Beban tugas; efikasi diri; kepuasan kerja; pendidikan teknik dan vokasional

(C) 2017 Penerbit UTM Press. All rights reserved

\subsection{PENGENALAN}

Kerancakan pembangunan negara terletak pada sumber manusianya, dan kekuatan tenaga kerja bergantung kepada kualiti pendidikan dalam membangunkan sumber manusia yang inovatif dan mencorak negara pada dekad akan datang (Ramlee, 2013). Dalam usaha menuju ke arah negara maju, peranan guru dalam sistem pendidikan adalah penting diberi perhatian kerana kecemerlangan guru dilihat sebagai kayu pengukur yang menentukan kualiti sistem pendidikan (Chughati \& Perveen, 2013). Bagi mencapai objektif pendidikan negara untuk melahirkan graduan sebagai sumber tenaga yang berkualiti, efikasi diri dan kepuasan kerja pendidik sangat penting dititikberatkan oleh semua pihak, kerana terbukti bukan sahaja penting untuk dirinya, tetapi juga organisasi. Pendidik yang memiliki efikasi diri yang tinggi menunjukkan sikap keterbukaan, mempunyai kemahiran berkomunikasi dengan baik, keinginan bekerjasama, serta berusaha sehabis baik dalam kerjaya (Tschannen-Moran \& Hoy, 2001). Sementara itu menurut Ramlee (2009), individu yang memperoleh kepuasan kerja yang tinggi akan termotivasi dan produktif dalam membantu sedaya upaya untuk mencapai matlamat organisasi. Pada hari ini, didapati tuntutantuntutan pekerjaan dan perubahan dasar dalam bidang pendidikan menyebabkan beban tugas yang ditanggung oleh guru semakin bertambah. Peningkatan beban tugas dalam tempoh waktu yang terbatas dan kekurangan sumber menyebabkan ramai guru membuat keputusan memilih bidang pekerjaan yang lain (Crotwell, 2011). Guru sebagai pendidik bukan sahaja perlu melaksanakan tugas hakiki iaitu mengajar di dalam kelas, bahkan juga menguruskan aktiviti kokurikulum, hal ehwal murid, pentadbiran dan pengkeranian serta kerja-kerja tambahan lain yang perlu dibuat mengikut keperluan semasa. Pelbagai tugas rencam ini dilihat menjejaskan masa berkualiti guru bagi melaksanakan proses pengajaran dan pembelajaran yang merupakan tugas utama seorang guru (Surat Siaran Kementerian Pendidikan Malaysia Bil. 20, 2014). 


\section{Tujuan Dan Objektif Kajian}

Secara umumnya, kajian ini bertujuan untuk mengenal pasti hubungan antara beban tugas dengan efikasi diri dan kepuasan kerja dalam kalangan pensyarah di kolej vokasional. Secara khususnya, objektif bagi kajian ini adalah seperti yang berikut :

1. Mengenal pasti perbezaan beban tugas pensyarah vokasional di kolej vokasional berdasarkan faktor demografi.

2. Mengenal pasti perbezaan efikasi diri pensyarah vokasional di kolej vokasional berdasarkan faktor demografi.

3. Mengenal pasti perbezaan kepuasan kerja pensyarah vokasional di kolej vokasional berdasarkan faktor demografi.

4. Mengenal pasti hubungan antara beban tugas dengan efikasi diri pensyarah vokasional di kolej vokasional.

5. Mengenal pasti hubungan antara beban tugas dengan kepuasan kerja pensyarah vokasional di kolej vokasional.

6. Mengenal pasti hubungan antara efikasi diri dengan kepuasan kerja pensyarah vokasional di kolej vokasional.

\subsection{SOROTAN LITERATUR}

Untuk menjadi seorang pendidik yang berkesan, masa merupakan antara sumber yang paling sukar diurus, terutamanya dengan peningkatan tanggungjawab dan tugas yang diperlukan (Ballet, Kelchtermans \& Loughran, 2006). Guru-guru yang berjaya menguruskan masa mereka dalam situasi beban tugas yang semakin meningkat dari masa ke masa lebih cenderung untuk kekal dalam profesion perguruan berbanding mereka yang tidak dapat menguruskan masa dan tugas yang diamanahkan (Bartlett, 2004). Justeru itu, peningkatan beban tugas dalam kalangan guru dan masa mengurus yang sangat terhad telah menyebabkan ramai guru memilih laluan kerjaya yang lain (Crotwell, 2011). Ini bertekalan dengan pandangan Hargreaves (2003) yang menyatakan bahawa:

Teaching, though vital to the knowledge economy, is now a profession that more and more people want to leave, fewer and fewer want to join, and very few are interested in leading and that is a crisis of disturbing proportions. (p.2)

Di Amerika Syarikat, Clark (2010) mendapati 40\% daripada guru-guru telah tawar hati terhadap kerjaya perguruan dan $16 \%$ guru meninggalkan profesion perguruan pada setiap tahun. Sebuah kajian di Amerika Syarikat menunjukkan kadar keperluan guru bagi menggantikan jawatan guru yang meninggalkan sekolah meningkat daripada $63.5 \%$ pada tahun 2002 kepada $86.3 \%$ pada 2004 (Marvel et. al., 2006). Pada tahun 2004 hingga 2005, guru-guru yang meninggalkan sekolah ditemubual, daripada keseluruhan responden, 25.7\% telah berpindah ke sekolah lain dan $35.7 \%$ telah meninggalkan profesion perguruan. 55\% daripada guru-guru yang telah berpindah ke sekolah lain menyatakan bahawa mereka dapat mengurus pekerjaan degngan lebih baik di sekolah baharu. Sementara itu, 65\% daripada guru-guru yang telah meletak jawatan menyatakan bahawa dan dapat menyesuaikan kehidupan dengan pekerjaan baru mereka (Marvel et. al., 2006).

Beban kerja yang berat menyebabkan guru berasa letih, sangat terbeban, dan tertekan (Buchanan, 2009). Guru sebagai pendidik bukan sahaja perlu melaksanakan tugas hakiki iaitu mengajar di dalam kelas, bahkan juga menguruskan aktiviti kokurikulum, hal ehwal murid, pentadbiran dan perkeranian serta beberapa kerja tambahan lain yang perlu dibuat mengikut keperluan semasa. Pelbagai tugas rencam ini dilihat menjejaskan masa berkualiti guru bagi melaksanakan proses pengajaran dan pembelajaran yang merupakan tugas utama seorang guru (Surat Siaran Kementerian Pendidikan Malaysia Bil. 20, 2014). Masalah beban tugas yang tinggi boleh menyumbang kepada stress dan masalah kesihatan yang yang lain. Di Malaysia, satu kajian telah dibuat oleh Kesatuan Perkhidmatan Perguruan Kebangsaan (NUTP) pada tahun 2005 mengenai stres di kalangan 9328 orang kakitangan perguruan di seluruh negara mendapati $69 \%$ responden menyatakan bahawa mereka bekerja dalam keadaan stres (Utusan Malaysia, 29 Mac 2006).

Antara impak beban tugas yang berat dihadapi oleh guru-guru adalah meninggalkan kerjaya. Smithers and Robinson (2001) mendapati bahawa tiga faktor utama yang menyebabkan guru meninggalkan kerjaya perguruan di England dan Wales adalah beban tugas, tingkahlaku pelajar, dan inisiatif kerajaan. Ini selari dengan kenyataan Crotwell (2011) yang berpendapat bahawa antara faktor guru meninggalkan kerjaya adalah kerana beban tugas dan gaji yang tidak berpadanan dengan tugas. Selain itu, Alliata, Benninghoff dan Müller (2009) juga menyatakan faktor utama yang menyebabkan guru-guru meninggalkan kerjaya adalah beban tugas, kerana mereka tidak mampu menguruskan beban tugas sehari-hari. Dari aspek motivasi kerja pula, beban tugas yang berat dilihat sebagai faktor yang menurunkan motivasi individu. Sebuah kajian "Market \& Opinion Research International" (MORI) dijalankan terhadap 70,000 guru di England bagi mengenalpasti faktor-faktor yang mengurangkan motivasi kerja. Sebanyak 56\% responden mendapati 'beban tugas' sebagai faktor utama yang menyumbang kepada pengurangan motivasi kerja, diikuti dengan 'beban inisiatif', 'budaya', dan 'tingkahlaku pelajar'. Beban tugas yang berat juga mempengaruhi tahap stres bagi guru. Ini kerana, tugas yang diagihkan secara tidak adil oleh pihak pentadbir menyebabkan guru berasa stres kerana terpaksa membuat kerja yang lebih dalam masa yang singkat berbanding guru lain (Punanesvaran, 2000).

Beban tugas yang melampau boleh menyumbang kepada masalah kesihatan yang berkaitan dengan stres, termasuklah masalah kesihatan mental (Ganster, Fox \& Dwyer, 2001) serta risiko diserang penyakit barah, sakit jantung dan tekanan darah tinggi (Utusan Malaysia, 2008). Rekod NUTP menunjukkan bahawa pada tahun 2004, sebanyak 79 kes penyakit kritikal melibatkan guru dilaporkan, 100 kes pada tahun 2005, 106 kes pada tahun 2006, dan 125 kes pada tahun 2007. Masalah kesihatan ini bukan sahaja merugikan pekerja, malahan memberi kesan negatif kepada organisasi kerana menanggung kos dan kekurangan tenaga kerja.

\section{Kepuasan Kerja}

Paulik (2012) mentakrifkan kepuasan kerja sebagai fenomena yang dialami berdasarkan penilaian kognitif bagi situasi pekerjaan mereka secara umum dengan mengambil kira perkara positif dan negatif. Dalam usaha sesebuah organisasi meningkatkan produktiviti, kepuasan kerja perlu ditingkatkan terlebih dahulu kerana sekiranya kakitangan gembira dalam bekerja, tahap efisyen yang tinggi akan dapat dicapai. Kebanyakan individu yang bekerja memperuntukkan masa yang panjang di tempat kerja, jadi ketidakpuasan kerja sudah tentu banyak mempengaruhi emosi dan kebahagiaan hidup dalam seharian (Lanner, 2010).

Terdapat banyak alasan mengapa aspek kepuasan kerja dalam kalangan guru sangat penting dititikberatkan. Antaranya adalah kerana kepuasan kerja mempunyai kesan kepada kualiti pengajaran dan kecemerlangan sekolah (Somech \& Drach-Zahavy, 2000). Sejak akhir-akhir 
ini, banyak tinjauan menunjukkan bahawa terdapat guru-guru yang tidak komited kepada kerjaya mereka dan ini berlaku atas faktor tekanan kerja, konflik peribadi, kekaburan peranan, masalah disiplin pelajar sebagai serta kekurangan sistem sokongan sosial cabaran yang dihadapi oleh guru-guru (Ramlee, 2009). Tekanan ini bukan sahaja menjejaskan emosi dan kesejahteraan fizikal guru, malahan boleh membawa kepada kepuasan kerja yang rendah.

Menurut Cropley, Dijk \& Stanley (2006), sesetengah pekerjaan seperti pendidikan dikenal pasti mempunyai beban tugas yang berat, dan ia merupakan faktor yang mempengaruhi kepuasan kerja individu secara negatif (Butt \& Lance, 2005). Apabila guru-guru terbeban dengan waktu bekerja yang lebih panjang daripada yang sepatutnya, konflik dalam pekerjaan berlaku dan ini mungkin menyebabkan ketidakpuasan kerja dan hilangnya minat untuk mengajar (Ehrhart, Klein \& Major, 2002). Banyak kajian dijalankan untuk mengenal pasti sumber dan faktor-faktor yang mempengaruhi kepuasan kerja guru (Butt et al., 2005), dan didapati kepuasan kerja guru dipengaruhi oleh faktor intrinsik dan ekstrinsik (Johnson, 2006). Faktor-faktor intrinsik adalah kuasa dan motivasi berkaitan dengan persepsi guru terhadap kemampuan diri (Hargreaves, 1997), hubungan dengan pelajar, ciri-ciri pelajar serta autonomi dan kebebasan guru (Zembylas \& Papanastasiou 2006). Sementara itu, faktor-faktor ekstrinsik termasuklah gaji, beban kerja, keadaan kerja, sokongan daripada pentadbir dan rakan-rakan serta pembangunan profesional (Zembylas \& Papanastasiou, 2006), dan pengaruh kepuasan kerja guru.

Antara kajian yang menunjukkan kesan positif beban tugas terhadap kepuasan kerja dijalankan oleh Chen (2010) di China yang mendapati beban tugas dan tekanan pekerjaan yang rendah, serta peluang meningkatkan taraf hidup melalui pekerjaan menyebabkan guru mempunyai kepuasan kerja yang tinggi. Selain itu, hubungan antara beban kerja dan kepuasan kerja dapat dilihat berdasarkan beberapa siri kajian yang melibatkan sampel yang guru-guru agak besar di Republik Czech dan Slovakia iaitu kajian Paulík pada tahun 1999, 2007, 2009, 2011; Paulik, 2012). Untuk semua sampel guru yang diuji, hubungan antara kepuasan kerja dan beban kerja adalah negatif dengan pekali korelasi $\mathrm{r}=-0.60$, menunjukkan bahawa peningkatan tekanan dalam kalangan guru menyumbang kepada penurunan tahap kepuasan kerja mereka. Ramlee (2011) dalam kajiannya bagi mengenalpasti faktor yang mempengaruhi kepuasan kerja guru vokasional mendapati sebanyak $64.4 \%$ responden mempunyai kepuasan kerja yang rendah. Faktor utamanya adalah kerana keadaan pekerjaan yang tidak memuaskan, di samping perlu mengendalikan kelas teori dan sesi praktikal serta pelbagai tugas yang lain.

\section{Efikasi Diri}

Konsep efikasi diri mempunyai kaitan dengan tahap kepercayaan individu yang mempengaruhi tingkah lakunya apabila berhadapan dengan sesuatu keadaan dan memberikan keupayaan untuknya melakukan tindakan yang diperlukan. Dalam erti kata yang lain, ia melibatkan pertimbangan terhadap tahap keupayaan diri dalam mempengaruhi hasil pembelajaran pelajar. Efikasi diri yang tinggi bukan sahaja mampu memberikan seseorang guru keyakinan dan kejayaan dalam melaksanakan tugasnya, malah ia dikenal pasti mempunyai hubungan yang signifikan dengan pencapaian pelajar (Bandura 1993, 1997; Tschannen-Moran \& Hoy 2001).

Menurut Bandura (1997), efikasi diri adalah penilaian seseorang atau kompetennya untuk melaksanakan sebuah tugas, mencapai tujuan atau mengatasi halangan. Semakin tinggi aras efikasi diri yang dimiliki, semakin yakin individu tersebut akan kemampuannya untuk menyelesaikan tugas tersebut. Justeru itu, individu yang memiliki aras efikasi diri yang rendah semakin mudah melepaskan tugas.

Efikasi diri guru yang tinggi mampu menyumbang kepada peningkatan pencapaian pelajar kerana guru yang memiliki aras efikasi diri yang tinggi menerapkan strategi pengalaman masteri berbanding guru yang rendah efikasi diri pengajarannya (Gibson \& Dembo 1984). Kepercayaan efikasi diri yang tinggi mendorong guru supaya lebih berusaha dengan gigih dalam tugas pengajarannya dengan mempelbagaikan aktiviti pengajaran dan tidak mudah mengalah (Tschannen-Moran \& Hoy 2001). Justeru, isu efikasi diri dalam kalangan guru perlu diberi perhatian supaya dapat menjamin mutu pendidikan di Malaysia secara menyeluruh.

Walaupun terminologi beban tugas, efikasi diri dan kepuasan kerja guru tidak asing lagi bagi penyelidik-penyelidik di luar negara, elemen ini masih dianggap sebagai baru dalam dunia pendidikan di negara kita. Meskipun terdapat beberapa kajian yang mengaitkan beban tugas guru dengan efikasi diri dan kepuasan kerja guru, namun perbezaan dapatan yang diperoleh menuntut lebih banyak kajian serupa dijalankan. Di samping itu, kajian-kajian yang mengaitkan beban tugas dan efikasi diri guru dengan kepuasan kerja guru masih kurang diberi tumpuan, khususnya dalam konteks pendidikan di Malaysia. Ini berlaku mungkin disebabkan kurangnya perlaksanaan kajian-kajian berkaitan aspek berkenaan (Poon, 1997). Kepuasan kerja dan efikasi diri memberi implikasi ke atas keseluruhan prestasi kerja seseorang, menyebabkan sesetengah guru menambah atau mengurangkan usaha dalam kerjaya. Ia juga merupakan faktor penting yang menyumbang kepada keputusan samada untuk terus kekal ataupun meninggalkan profesion (Locklear, 2010).

\subsection{METODOLOGI KAJIAN}

Kajian ini merupakan sebuah kajian berbentuk korelasi. Pendekatan kuantitatif digunakan dan data dikumpulkan menggunakan instrumen soal selidik. Menurut data yang diperolehi daripada Bahagian Perancangan dan Penyelidikan Data Pendidikan pada Januari 2014, jumlah keseluruhan tenaga pengajar di kolej vokasional adalah seramai 6,582 orang (Jadual 1). Berpandukan jadual Krejchie dan Morgan (1970), jumlah sampel kajian yang bersesuaian bagi populasi seramai 7,000 orang adalah seramai 364 orang.

Jadual 1 Bilangan pensyarah kolej vokasional di Malaysia mengikut kelulusan

\begin{tabular}{cc}
\hline Kategori & Bilangan \\
\hline Pensyarah Berijazah & 5,728 \\
Pensyarah Tidak Berijazah & 837 \\
Tidak Terlatih & 17 \\
\hline JUMLAH & 6,582 \\
\hline
\end{tabular}

Sebanyak 500 borang soal selidik telah diedarkan kepada 15 buah kolej vokasional yang dipilih mengikut zon menggunakan teknik persampelan rawak kluster. Setelah tamat proses pengumpulan data, sebanyak 401 borang soal selidik telah dipulangkan. Terdapat borang 
soal selidik yang tidak lengkap dan tidak boleh digunakan iaitu sebanyak 28 borang. Secara keseluruhannya, sebanyak 373 borang soal selidik yang lengkap dan boleh digunakan untuk diproses. Dengan itu, peratusan julat respon kajian ini adalah sebanyak 80.2 peratus dan peratusan soal selidik yang lengkap adalah sebanyak 74.6\%. Data diproses menggunakan perisian SPSS versi 21 menggunakan kaedah deskriptif (min dan sisihan piawai) dan statistik inferensi (ujian- $t$ dua kumpulan tak bersandar, ANOVA dan kolerasi Pearson-r).

\section{Kerangka Konseptual Kajian}

Rajah 1 menunjukkan kerangka konseptual bagi kajian ini. Ia dibina berpandukan beberapa model dan teori yang merangkumi aspek beban tugas, efikasi diri dan kepuasan kerja.

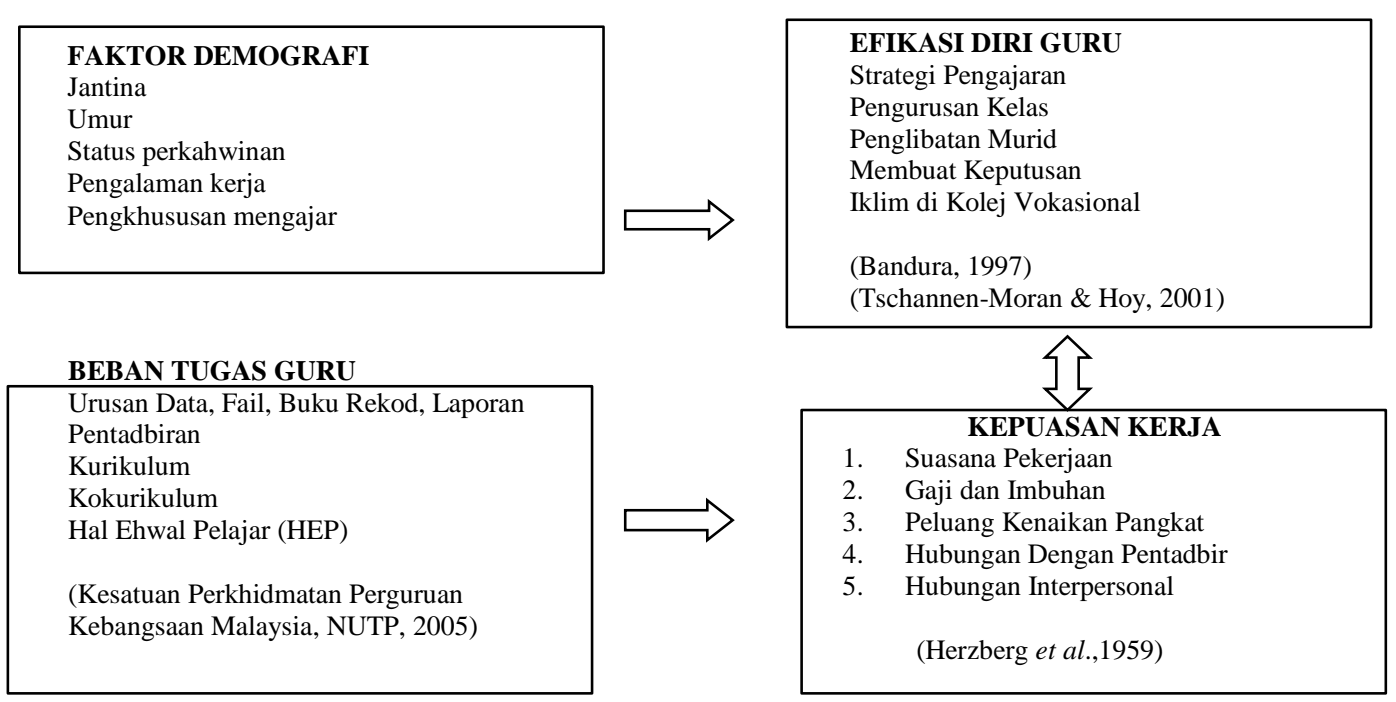

Rajah 1 Kerangka konseptual kajian

\subsection{DAPATAN KAJIAN}

Jadual 2 menunjukkan hasil keputusan Cronbach's Alpha bagi setiap pembolehubah dan mendapati kesemua nilai melebihi 0.700. Nilai Cronbach's Alpha adalah bermula 0.885 higga 0.909. Keputusan analisis ini mendapati bahawa pembolehubah mempunyai item-item pengukuran yang dikehendaki dan dipercayai. Keseluruhannya, tiada sebarang item perlu dibuang bagi setiap pembolehubah. Dari sudut kekuatan pula, beban tugas $(\alpha=0.909)$ mempunyai kekuatan yang cemerlang. Manakala efikasi diri $(\alpha=0.886)$ dan kepuasan kerja $(\alpha=0.885)$ mempunyai kekuatan sangat baik. Nilai keseluruhan Cronbach's Alpha bagi kesemua 60-item adalah sebanyak 0.905, berada dalam kebolehpercayaan yang cemerlang. Dapatan ini menunjukkan item-item yang dibina bagi mengukur setiap pembolehubah kajian berada ditahap yang cemerlang kebolehpercayaannya.

Jadual 2 Kesahan instrumen kajian melalui ujian Cronbach's Alpha

\begin{tabular}{|c|c|c|c|}
\hline Dimensi/Pembolehubah & Cronbach's Alpha & Jumlah Item & Kekuatan \\
\hline Beban Tugas & 0.909 & 20 & Cemerlang \\
\hline Efikasi Diri & 0.886 & 20 & Sangat Baik \\
\hline Kepuasan Kerja & 0.885 & 20 & Sngat Baik \\
\hline Keseluruhan & 0.905 & 60 & Cemerlang \\
\hline
\end{tabular}

Analisis deskriptif yang digunakan adalah min dan sisihan piawai. Tahap skor min diukur dengan merujuk cara penyelidik Hishamuddin (2005) seperti tertera dalam Jadual 3.

Jadual 3 Tahap penerimaan julat min

\begin{tabular}{cc}
\hline Tahap Penerimaan & Julat Min \\
\hline Tinggi & $3.68-5.00$ \\
Sederhana & $2.34-3.67$ \\
Rendah & $1.00-2.33$
\end{tabular}


Tahap Beban Tugas, Efikasi Diri dan Kepuasan Kerja Pensyarah di Kolej Vokasional

Jadual 4 menunjukkan dapatan analisis tahap beban tugas pensyarah vokasional di kolej vokasional. Secara keseluruhannya, beban tugas yang ditanggung oleh pensyarah vokasional adalah tinggi $(\min =3.68, \mathrm{sp}=0.77)$. Domain beban tugas yang paling berat pada perspektif responden adalah tugas-tugas sampingan diikuti beban kurikulum. Tugas-tugas sampingan yang yang perlu dilaksanakan oleh pensyarah merangkumi tugas mengurus data, melengkapkan fail, menyediakan laporan dan lain-lain. Sementara itu, tiga domain lain mencatat nilai min yang sederhana.

Jadual 4 Tahap beban tugas pensyarah kolej vokasional

\begin{tabular}{|c|c|c|c|}
\hline Domain Beban Tugas & Skor Min & Sisihan Piawai & Tahap \\
\hline Pentadbiran & 3.37 & 0.81 & Sederhana \\
\hline Kurikulum & 3.84 & 0.74 & Tinggi \\
\hline Kokurikulum & 3.58 & 0.85 & Sederhana \\
\hline Hal Ehwal Pelajar (HEP) & 3.60 & 0.77 & Sederhana \\
\hline Tugas-tugas Sampingan & 4.00 & 0.69 & Tinggi \\
\hline Beban Tugas & 3.68 & 0.77 & Tinggi \\
\hline
\end{tabular}

Jadual 5 menunjukkan dapatan analisis tahap efikasi diri pensyarah vokasional di kolej vokasional. Efikasi diri pensyarah vokasional didapati berada pada tahap yang tinggi ( $\min =3.81, \mathrm{sp}=0.57$ ). Kebanyakan domain efikasi mencatatkan nilai min pada tahap yang tinggi kecuali domain membuat keputusan yang mendapat min pada tahap yang sederhana. Domain yang mendapat nilai min tertinggi adalah pengurusan kelas dan diikuti oleh domain strategi pengajaran.

Jadual 5 Tahap efikasi diri pensyarah kolej vokasional

\begin{tabular}{cccc}
\hline Domain Efikasi Diri & Skor Min & Sisihan Piawai & Tahap \\
\hline Strategi Pengajaran & 3.83 & 0.56 & Tinggi \\
Pengurusan Kelas & 3.99 & 0.48 & Tinggi \\
Penglibatan Murid & 4.06 & 0.51 & Tinggi \\
Membuat Keputusan & 3.40 & 0.64 & Sederhana \\
Iklim di Kolej Vokasional & 3.77 & 0.51 & Tinggi \\
\hline Efikasi Diri & 3.81 & 0.57 & Tinggi \\
\hline
\end{tabular}

Jadual 6 menunjukkan dapatan analisis kepuasan kerja pensyarah vokasional di kolej vokasional. Secara keseluruhannya, kepuasan kerja pensyarah berada pada tahap yang sederhana dengan min $3.57(\mathrm{sp}=0.530)$. Dua domain mendapat nilai min pada tahap yang tinggi iaitu hubungan interpersonal diikuti oleh suasana pekerjaan. Ini menunjukkan responden sangat berpuas hati dalam perkara yang melibatkan hubungan sesama rakan sekerja dan juga suasana pekerjaan mereka. Sementara itu, domain lain mencatatkan nilai min pada tahap yang sederhana.

Jadual 6 Tahap kepuasan kerja pensyarah kolej vokasional

\begin{tabular}{cccc}
\hline Domain & Skor Min & Sisihan Piawai & Tahap \\
\hline Suasana Pekerjaan & 3.69 & 0.58 & Tinggi \\
Gaji dan Imbuhan & 3.25 & 0.94 & Sederhana \\
Peluang Kenaikan Pangkat & 3.63 & 0.69 & Sederhana \\
Hubungan dengan Pentadbir & 3.31 & 0.65 & 0.56 \\
Hubungan interpersonal & 3.96 & 0.53 & Tinggi \\
\hline Kepuasan Kerja & 3.57 & Sederhana \\
\hline
\end{tabular}

Perbezaan Tahap Beban Tugas, Efikasi Diri Dan Kepuasan Kerja Mengikut Demografi

Ujian-t dua kumpulan tidak bersandar dan ANOVA sehala dilakukan bagi menguji perbezaan tahap beban tugas, efikasi diri dan kepuasan kerja mengikut faktor demografi responden iaitu jantina, umur, status perkahwinan, tempoh perkhidmatan, dan pengkhususan pengajaran. Jadual 7 menunjukkan hasil analisis yang dijalankan bagi melihat perbezaan beban tugas, efikasi diri dan kepuasan kerja responden mengikut faktor demografi. 
Jadual 7 Analisis perbezaan tahap beban tugas, efikasi diri dan kepuasan kerja mengikut demografi

\begin{tabular}{|c|c|}
\hline Bil. & Dapatan analisis \\
\hline 1 & $\begin{array}{l}\text { Tidak terdapat perbezaan yang signifikan dalam aspek beban tugas pensyarah mengikut faktor jantina, umur, status perkahwinan, dan } \\
\text { pengkhususan pengajaran berdasarkan nilai-p yang melebihi aras keertian } 0.05 \text {. }\end{array}$ \\
\hline 2 & $\begin{array}{l}\text { Terdapat perbezaan yang signifikan dalam aspek beban tugas pensyarah mengikut tempoh perkhidmatan }(\mathrm{p}=0.02<0.05) \text {. Pensyarah yang } \\
\text { berkhidmat antara } 31 \text { hingga } 45 \text { tahun mempunyai persepsi beban tugas tertinggi }(\min =2.86) \text {. }\end{array}$ \\
\hline 3 & $\begin{array}{l}\text { Tidak terdapat perbezaan yang signifikan dalam aspek efikasi diri pensyarah mengikut faktor jantina dan status perkahwinan berdasarkan } \\
\text { nilai-p yang melebihi aras keertian } 0.05 \text {. }\end{array}$ \\
\hline 4 & $\begin{array}{l}\text { Terdapat perbezaan yang signifikan dalam aspek efikasi diri pensyarah mengikut faktor umur }(\mathrm{p}=0.008<0.05) \text {. Pensyarah yang berumur } \\
\text { melebihi } 45 \text { tahun mempunyai tahap efikasi diri tertinggi berbanding peringkat umur yang lain }(\min =3.95) \text {. }\end{array}$ \\
\hline 5 & $\begin{array}{l}\text { Terdapat perbezaan yang signifikan dalam aspek efikasi diri pensyarah mengikut tempoh perkhidmatan }(\mathrm{p}=0.010<0.05) \text {. Skor min efikasi } \\
\text { diri bagi pensyarah yang berkhidmat selama } 31 \text { hingga } 45 \text { tahun adalah yang tertinggi iaitu } 3.96 \text {, manakala skor min terendah adalah bagi } \\
\text { pensyarah yang bekerja kurang daripada } 10 \text { tahun iaitu } 3.74 \text {. }\end{array}$ \\
\hline 6 & $\begin{array}{l}\text { Terdapat perbezaan yang signifikan dalam aspek efikasi diri pensyarah mengikut pengkhususan pengajaran }(\mathrm{p}=0.000<0.05) \text {. Pensyarah } \\
\text { yang mengajar dalam bidang Teknologi Kejuruteraan Mekanikal mempunyai skor min efikasi diri yang tertinggi iaitu } 4.16 \text {. }\end{array}$ \\
\hline 7 & $\begin{array}{l}\text { Terdapat perbezaan yang signifikan dalam aspek kepuasan kerja pensyarah mengikut jantina }(\mathrm{t}=2.261, \mathrm{p}=0.024<0.05) \text {. Pensyarah lelaki } \\
\text { didapati mempunyai skor min kepuasan kerja yang lebih tinggi }(\min =3.63) \text { berbanding pensyarah perempuan }(\min =3.51) \text {. }\end{array}$ \\
\hline 8 & $\begin{array}{l}\text { Tidak terdapat perbezaan yang signifikan dalam aspek kepuasan kerja pensyarah mengikut faktor umur dan status perkahwinan berdasarkan } \\
\text { nilai-p yang melebihi aras keertian } 0.05 \text {. }\end{array}$ \\
\hline 9 & $\begin{array}{l}\text { Terdapat perbezaan yang signifikan dalam aspek kepuasan kerja pensyarah mengikut tempoh perkhidmatan }(\mathrm{p}=0.001<0.05) \text {. Skor min } \\
\text { kepuasan kerja bagi pensyarah yang berkhidmat selama } 31 \text { hingga } 45 \text { tahun adalah yang tertinggi iaitu } 3.92 \text {, manakala skor min terendah } \\
\text { adalah bagi pensyarah yang bekerja kurang daripada } 10 \text { tahun iaitu } 3.46 \text {. }\end{array}$ \\
\hline 10 & $\begin{array}{l}\text { Terdapat perbezaan yang signifikan dalam aspek kepuasan kerja pensyarah mengikut pengkhususan pengajaran }(\mathrm{p}=0.008<0.05) \text {. Pensyarah } \\
\text { yang mengajar dalam bidang Teknologi Kejuruteraan Mekanikal mempunyai skor min kepuasan kerja yang tertinggi iaitu } 4.00 \text {. }\end{array}$ \\
\hline
\end{tabular}

Hubungan Antara Beban Tugas Dengan Efikasi Diri

\section{Hipotesis Nol: Tidak Terdapat Hubungan Yang Signifikan Antara Beban Tugas Dengan Efikasi Diri Dalam Kalangan Pensyarah Di Kolej Vokasional}

Jadual 8 menunjukkan keputusan analisis korelasi antara pembolehubah beban tugas dengan efikasi diri. Hasil analisis mendapati terdapat hubungan yang signifikan antara beberapa aspek beban tugas dan efikasi diri berdasarkan nilai-p yang kurang daripada aras keertian 0.05 . Wujud hubungan yang lemah dalam arah negatif antara domain kurikulum dengan pengurusan kelas dan strategi pengajaran, domain kokurikulum dengan strategi pengajaran, domain hal ehwaal pelajar dengan penglibatan murid, domain tugas-tugas sampingan dengan pengurusan kelas dan iklim di kolej vokasional. Justeru itu, hipotesis nol berjaya ditolak dan membuktikan bahawa terdapat hubungan yang lemah dalam arah negatif antara beban tugas dengan efikasi diri.

Jadual 8 Hubungan di antara beban tugas dan efikasi diri

\begin{tabular}{|c|c|c|c|c|c|c|}
\hline & & $\begin{array}{c}\text { Penglibatan } \\
\text { Murid } \\
\end{array}$ & $\begin{array}{c}\text { Pengurusan } \\
\text { Kelas } \\
\end{array}$ & $\begin{array}{c}\text { Strategi } \\
\text { Pengajaran } \\
\end{array}$ & $\begin{array}{c}\text { Membuat } \\
\text { Keputusan }\end{array}$ & Iklim di KV \\
\hline \multirow[t]{2}{*}{ Pentadbiran } & Korelasi Pearson & -.042 & -.019 & -.005 & -.007 & -.023 \\
\hline & Nilai-p (2-hujung) & .423 & .715 & .000 & .900 & .660 \\
\hline \multirow[t]{2}{*}{ Kurikulum } & Korelasi Pearson & -.016 & $-.280^{* *}$ & $-.167^{* *}$ & -.054 & -.108 \\
\hline & Nilai-p (2-hujung) & .759 & .002 & .001 & .294 & .068 \\
\hline \multirow[t]{2}{*}{ Kokurikulum } & Korelasi Pearson & -.090 & -.089 & $-.106^{*}$ & -.097 & -.031 \\
\hline & Nilai-p (2-hujung) & .083 & .087 & .040 & .062 & .545 \\
\hline \multirow[t]{2}{*}{ Hal Ehwal Pelajar } & Korelasi Pearson & $-.247 *$ & -.058 & -.050 & -.004 & -.080 \\
\hline & Nilai-p (2-hujung) & .036 & .267 & .332 & .940 & .125 \\
\hline \multirow[t]{2}{*}{ Tugas-tugas sampingan } & Korelasi Pearson & -.071 & $-.323^{*}$ & -.043 & -.002 & $-.114^{*}$ \\
\hline & Nilai-p (2-hujung) & .169 & .018 & .410 & .964 & .028 \\
\hline
\end{tabular}

Hubungan Antara Beban Tugas dengan Kepuasan Kerja

\section{Hipotesis Nol: Tidak Terdapat Hubungan Yang Signifikan Antara Beban Tugas Dengan Kepuasan Kerja Dalam Kalangan Pensyarah Di Kolej Vokasional}

Jadual 9 menunjukkan keputusan analisis korelasi antara beban tugas dengan kepuasan kerja. Hasil analisis mendapati terdapat hubungan yang signifikan antara beberapa aspek beban tugas dan kepuasan kerja berdasarkan nilai-p yang kurang daripada aras keertian 0.05. Wujud hubungan yang lemah dalam arah negatif antara domain pentadbiran dengan suasana pekerjaan, gaji dan imbuhan, serta hubungan interpersonal. Selain itu, wujud juga hubungan yang lemah dalam arah negatif antara domain kurikulum dengan hubungan dengan pentadbir, domain hal ehwal pelajar dengan suasana pekerjaan dan hubungan dengan pentadbir. Domain tugas-tugas sampingan dilihat mempunyai hubungan dalam arah negatif dengan domain gaji, hubungan dengan pentadbir dan juga hubungan interpersonal. Justeru itu, hipotesis nol berjaya ditolak dan membuktikan bahawa terdapat hubungan yang lemah dalam arah negatif antara beban tugas dengan kepuasan kerja. 
Jadual 9 Hubungan di antara beban tugas dan kepuasan kerja

\begin{tabular}{|c|c|c|c|c|c|c|}
\hline & & $\begin{array}{c}\text { Suasana } \\
\text { Pekerjaan }\end{array}$ & $\begin{array}{l}\text { Gaji dan } \\
\text { Imbuhan }\end{array}$ & $\begin{array}{c}\text { Peluang } \\
\text { Kenaikan } \\
\text { Pangkat }\end{array}$ & $\begin{array}{c}\text { Hubungan } \\
\text { dengan } \\
\text { Pentadbir }\end{array}$ & $\begin{array}{c}\text { Hubungan } \\
\text { interpersonal }\end{array}$ \\
\hline \multirow[t]{2}{*}{ Pentadbiran } & Korelasi Pearson & $-.260^{* *}$ & $-.194^{* *}$ & -.069 & -.217 & $-.387^{* *}$ \\
\hline & Nilai-p (2-hujung) & .002 & .000 & .181 & .181 & .000 \\
\hline \multirow[t]{2}{*}{ Kurikulum } & Korelasi Pearson & -.051 & -.239 & -.028 & $-.207^{* *}$ & -.044 \\
\hline & Nilai-p (2-hujung) & .324 & .175 & .589 & .000 & .394 \\
\hline \multirow[t]{2}{*}{ Kokurikulum } & Korelasi Pearson & -.086 & -.180 & -.121 & -.243 & -.115 \\
\hline & Nilai-p (2-hujung) & .096 & .066 & .552 & .085 & .226 \\
\hline \multirow[t]{2}{*}{ Hal Ehwal Pelajar } & Korelasi Pearson & $-.382^{*}$ & -.353 & -.096 & $-.227^{* *}$ & -.089 \\
\hline & Nilai-p (2-hujung) & .014 & .115 & .064 & .000 & .086 \\
\hline \multirow[t]{2}{*}{ Tugas-tugas sampingan } & Korelasi Pearson & -.127 & $-.250^{* *}$ & -.332 & $-.397^{* * *}$ & $-.224^{*}$ \\
\hline & Nilai-p (2-hujung) & .214 & .004 & .060 & .000 & .017 \\
\hline
\end{tabular}

Hubungan Antara Efikasi Diri dengan Kepuasan Kerja

\section{Hipotesis Nol: Tidak Terdapat Hubungan Yang Signifikan Antara Efikasi Diri Dengan Kepuasan Kerja Dalam Kalangan Pensyarah Di Kolej Vokasional}

Jadual 10 menunjukkan keputusan analisis korelasi antara beban tugas dengan kepuasan kerja. Hasil analisis mendapati terdapat hubungan yang signifikan antara beberapa aspek efikasi diri dan kepuasan kerja berdasarkan nilai-p yang kurang daripada aras keertian 0.05. Wujud hubungan yang sederhana kuat dalam arah positif antara domain penglibatan murid dengan suasana pekerjaan dan hubungan interpersonal, domain pengurusan kelas dengan suasana pekerjaan, domain strategi pengajaran dengan hubungan dengan pentadbir, domain membuat keputusan dengan hubungan dengan pentadbir, serta domain iklim di kolej vokasional dengan hubungan interpersonal. Justeru itu, hipotesis nol berjaya ditolak dan membuktikan bahawa terdapat hubungan yang sederhana kuat dalam arah positif antara efikasi diri dengan kepuasan kerja (Jadual 11).

Jadual 10 Hubungan di antara efikasi diri dan kepuasan kerja

\begin{tabular}{|c|c|c|c|c|c|c|}
\hline & & $\begin{array}{c}\text { Suasana } \\
\text { Pekerjaan }\end{array}$ & $\begin{array}{l}\text { Gaji dan } \\
\text { Imbuhan }\end{array}$ & $\begin{array}{c}\text { Peluang Kenaikan } \\
\text { Pangkat }\end{array}$ & $\begin{array}{l}\text { Hubungan dengan } \\
\text { Pentadbir }\end{array}$ & $\begin{array}{c}\text { Hubungan } \\
\text { Interpersonal }\end{array}$ \\
\hline \multirow[t]{2}{*}{ Penglibatan Murid } & Korelasi Pearson & $.404^{* *}$ & -.041 & .302 & .022 & $.358^{* *}$ \\
\hline & Nilai-p (2-hujung) & .000 & .430 & .325 & .218 & .000 \\
\hline \multirow{2}{*}{ Pengurusan Kelas } & Korelasi Pearson & $.415^{* *}$ & .064 & .227 & .117 & .316 \\
\hline & Nilai-p (2-hujung) & .000 & .215 & .323 & .124 & .212 \\
\hline \multirow[t]{2}{*}{ Strategi Pengajaran } & Korelasi Pearson & .229 & .040 & .128 & $.210^{*}$ & .064 \\
\hline & Nilai-p (2-hujung) & .331 & .445 & .064 & .033 & .220 \\
\hline \multirow{2}{*}{ Membuat Keputusan } & Korelasi Pearson & .321 & .079 & .330 & $.190^{* *}$ & .085 \\
\hline & Nilai-p (2-hujung) & .085 & .127 & .212 & .000 & .132 \\
\hline \multirow[t]{2}{*}{ Iklim di KV } & Korelasi Pearson & .352 & .132 & .313 & .210 & $.238^{* *}$ \\
\hline & Nilai-p (2-hujung) & .218 & .061 & .225 & .086 & .000 \\
\hline
\end{tabular}

Jadual 11 Hubungan antara beban tugas, efikasi diri dan kepuasan kerja

\begin{tabular}{|c|c|c|c|c|}
\hline & & Beban Tugas & Efikasi Diri & Kepuasan Kerja \\
\hline \multirow[t]{2}{*}{ Beban Tugas } & Korelasi Pearson & 1 & $-0.196 *$ & $-0.358 * *$ \\
\hline & Nilai-p (2-hujung) & & 0.046 & 0.000 \\
\hline \multirow[t]{2}{*}{ Efikasi Diri } & Korelasi Pearson & & 1 & $0.395 * *$ \\
\hline & Nilai-p (2-hujung) & & & 0.000 \\
\hline \multirow[t]{2}{*}{ Kepuasan Kerja } & Korelasi Pearson & & & 1 \\
\hline & Nilai-p (2-hujung) & & & \\
\hline
\end{tabular}

\subsection{PERBINCANGAN}

Analisis data kajian menunjukkan bahawa pensyarah vokasional di kolej vokasional menanggung beban tugas yang tinggi (min=3.73) terutamanya tugas-tugas pengkeranian, kurikulum dan pentadbiran. Tambahan lagi, tugas kurikulum mereka bertambah sejak penaiktarafan kolej vokasional kerana perlu menyediakan modul pengajaran bagi kursus yang diajar. Mereka juga bukan sahaja menanggung tugas umum seperti guru biasa, tetapi juga mempunyai tugas pengurusan bengkel seperti inventori, peralatan, bahan bengkel dan kebersihan (Azaruddin, 2004). Walau bagaimanapun, didapati tahap efikasi diri pensyarah berada pada tahap yang tinggi (min=3.81). Aspek yang mencatatkan skor min tertinggi adalah pengurusan kelas, strategi pengajaran dan penglibatan murid. Ini menunjukkan bahawa pensyarah vokasional mempunyai komitmen yang tinggi terhadap pengajaran dan pembelajaran di dalam kelas. Menurut Bandura (1977), semakin tinggi efikasi diri seseorang individu, semakin kuat usahanya dalam melaksanakan sesuatu. Kepercayaan efikasi diri yang tinggi mendorong guru supaya 
mempelbagaikan aktiviti pengajaran (Tschannen Moran \& Hoy, 2001).Walaupun dibebani dengan pelbagai tugas lain, namun sebagai pendidik aspek berkaitan pengajaran dan pembelajaran tetap diberi keutamaan. Kepuasan pensyarah secara keseluruhannya berada pada tahap yang sederhana $(\min =3.57)$. Aspek yang paling menyumbang kepada kepuasan kerja pensyarah adalah hubungan interpersonal, suasana pekerjaan, dan kenaikan pangkat. Manakala aspek yang mencatat nilai min terendah adalah yang berkaitan dengan gaji dan imbuhan. Apabila gaji yang diberikan dirasakan kurang setimpal dengan pekerjaan yang dilaksanakan, kepuasan kerja individu akan berkurangan (Herzberg, 1987).

Analisis korelasi antara pembolehubah beban tugas dan efikasi diri menunjukkan bahawa terdapat hubungan yang signifikan antara kedua-duanya dalam arah yang negatif. Ini menunjukkan bahawa dengan peningkatan beban tugas, efikasi diri akan berkurangan. Dapatan kajian juga menunjukkan hubungan yang signifikan antara beban tugas dengan kepuasan kerja dalam arah negatif. Ertinya, peningkatan beban tugas akan mengurangkan kepuasan kerja pensyarah. Ini selari dengan pandangan Ehrhart, Klein \& Major (2002) yang menyatakan bahawa apabila guru-guru terbeban dengan tugas yang lebih daripada sepatutnya, konflik dalam pekerjaan berlaku dan ini menyebabkan ketidakpuasan kerja dan hilangnya minat untuk mengajar. Menurut Cropley, Dijk dan Stanley (2006), sesetengah pekerjaan seperti pendidikan dikenal pasti mempunyai beban tugas yang berat, dan ia merupakan faktor yang mempengaruhi kepuasan kerja individu secara negatif (Butt \& Lance, 2005) dan menjadi faktor kepada persaraan awal bagi golongan guru (Mark, 2012). Hasil analisis juga menunjukkan terdapat hubungan yang signifikan yang positif antara efikasi diri dengan kepuasan kerja pensyarah vokasional. Ini disokong oleh pandangan Caprara (2003) yang menyatakan efikasi diri yang tinggi membawa kepada kepuasan kerja yang tinggi. Pendidik yang memiliki efikasi diri yang tinggi menunjukkan sikap keterbukaan, mempunyai kemahiran berkomunikasi dengan baik, keinginan bekerjasama dan dapatan ini bertekalan dengan kajian Belkis \& Mithat (2013) yang menunjukkan hubungan yang positif antara kedua-dua pembolehubah ini.

\subsection{KESIMPULAN}

Kajian yang dijalankan untuk mengenalpasti hubungan antara beban tugas dengan efikasi diri dan kepuasan kerja pensyarah di kolej vokasional. Berdasarkan analisis data, dapat disimpulkan bahawa beban tugas, efikasi diri dan kepuasan kerja mempunyai hubungan yang signifikan antara satu sama lain. Beban tugas yang seimbang dan tidak terlalu berat akan meningkatkan efikasi diri dan kepuasan pensyarah vokasional. Justeru itu, semua pihak khusunya Kementerian Pendidikan Malaysia, Bahagian Pendidikan Teknik dan Vokasional, dan pihak pentadbir perlu berusaha untuk mengurus isu beban tugas pensyarah vokasional dengan sebaik mungkin, disamping membekalkan sumbersumber yang diperlukan bagi memastikan masalah beban tugas akan dapat dikurangkan dengan berhemah seterusnya dapat meningkatkan kualiti pendidikan teknik dan vokasional di Malaysia secara menyeluruh.

\section{Rujukan}

Adams, J. S. (1965). Advance in Experimental Social Psychology. (2nd Edition). New York: Academy Press.

Alliata, R., Benninghoff, F., \& Müller, K. (2009). Attracting and Retaining Teachers: A Question Of Motivation, Educational Management Administration and Leadership, 37, 574- 599.

Azarudin (2004). Beban Tugas Guru Bengkel Dalam Pengurusan Bengkel Di Lima Buah Sekolah Menengah Teknik Di Negeri Sembilan. Universiti Teknologi Malaysia : Kajian Ijazah Sarjana Muda.

Ballet, K., \& Kelchtermans, \& Loughran, J. (2006). Beyond Intensification To A Scholarship Of Practice: Analyzing Changes In Teachers' Work Lives. Teachers and Teaching: Theory and Practice, 12(2), 209-229.

Bandura, A. (1997). Self-Efficacy: The Exercise of Control. New York: W. H. Freeman.

Bao, D. (2002). Dangjin Woguo Zhongxiaoxue Jiaoshi Xintai Daxing Diaocha Baodao (A Survey Of Primary And Secondary School Teachers In China). Chinese Education, 9 .

Bartlett, L. (2004). Expanding Teacher Work Roles: A Resource For Retention Or A Recipe For Overwork? Journal of Education Policy, $19(5), 565-582$.

Buchanan, J. (2009). Where Are They Now? Ex-Teachers Tell Their Life-Work Stories. Issues in Educational Research, 19(1), 1-13.

Butt, G., Lance, A., Fielding, A., Gunter, H., Rayner, S., \& Thomas, H. (2005). Teacher Job Satisfaction: Lessons from the TSW Pathfinder Project. School Leadership and Management, 25(5), 455-471.

Caprara, G.T., Barbaranelli, C., Steca P. \& Malone P.S. (2006). Teacher's Self Efficacy Beliefs As Determinants Of Jobs Satisfaction And Students' Academic Achievements: A Study At The School Level. Journal of School Psychology, 44(6), 473-490.

Chen, J. (2010). Chinese Middle School Teacher Job Satisfaction And Its Relationships With Teacher Moving. Asia Pacific Educ. Rev, 11, 263-272

Cheung, R. (2009). Nurturing Commitment To Struggling Students: Here Are Some Strategies School Leaders Can Use To Sustain The Efforts Of Committed Teachers And Reduce Teacher Burnout. Leadership, 16-19.

Chughati, F. D. \& Perveen, U. (2013) A study of Teachers Workload And Job Satisfaction In Public And Private Schools At Secondary Level in Lahore City Pakistan. Asian Journal of Social Sciences \& Humanities, 2(1), 202-214.

Clark, K. (2010). The Extreme School Makeover. US News and World Report, 25-31.

Cropley, M., Dijk, D. J., \& Stanley, N. (2006). Job Strain, Work Rumination, And Sleep In School Teachers. European Journal of Work and Organisational Psychology, 15(2), 181-196.

Crotwell, W. G. (2011). Elementary School Teachers' Experience Of Professional Workload And Time. Ph.D Thesis. Walden University.

Currall, S. C., Towler, A. J., Judge, T., \& Kohn, L. (2005). Pay Satisfaction And Organizational Outcomes. Personnel Psychology, 58, 613-640.

Day, C. (2004). A Passion For Teaching. London: Routledge Falmer.

Day, C. (2008). Committed For Life? Variations In Teachers' Work, Lives And Effectiveness. Springer, 243-260.

Day, C. \& Smethem, E. L. (2009). The Effects Of Reform: Have Teachers Really Lost Their Sense Of Professionalism? Journal of Educational Change, $10,141-157$.

Ehrhart, G. M., Klein, J. K., \& Major, S. V. (2002). Work Time, Work Interference With Family, And Psychological Distress. Journal of Applied Psychology, 87(3), 427-436.

Ganster, D. C., Fox, M. L., \& Dwyer, D. J. (2001). Explaining Employees' Health Care Costs: A Prospective Exam Ination Of Stressful Job Demands, Personal Control, And Physiological Reactivity. Journal of Applied Psychology, 86(1), 954-964.

Gleibermann, E. (2007). Teaching Even 100 Hours A Week Leaves Children Behind. Phi Delta Kappan, 88(6), 455-459.

Greiner, C., \& Smith, B. (2006). Determining The Effect Of Selected Variables On Teacher Retention. Education, 126(4), 653-659.

Groenewegen, P. P. \& Hutten, J. B. (1991). Workload and Job Satisfaction Among General Practitioners: A Review Of The Literature. Pergamon Press PLC, 32(10), 1111-1119.

Hall, B. W., Pearson, L. Carolyn; C., \& DeLos. (1992). Teachers' Long-Range Teaching Plans: A Discriminant Analysis. Journal of Educational Research, 85, 221225 . 
Hargreaves, A. (1997). Positive Change For School Success: The 1997 ASCD Yearbook. Alexandria, VA: Association for Supervision and Curriculum Development. Herzberg, F., Mausner, B. \& B. Synderman. (1959). The Motivation To Work (2 ${ }^{\text {nd }}$ edition). New York: John Wiley \& Sons.

Ingersoll, R. M. (2003). Who controls teachers' work? Cambridge, MA: Harvard University Press.

Johnson, M. D (2006). The Effect Of Workload On Individual And Team Learning, Affect, And Performance. Ph.D Dissertation, Michigan State University.

Kesatuan Perkhidmatan Perguruan Kebangsaan (NUTP). (2005). Pandangan dan Syor NUTP: Beban guru. Kuala Lumpur: Kesatuan Perkhidmatan Perguruan Kebangsaan.

Krejcie, R. V., \& Morgan, D. W. (1970). Determining Sample Size For Research Activities. Educational and Psychological Measurement, $30(1), 608-618$.

Lam, P., Foong, Y., Moo, S. N. (1995). Work Life, Career Commitment, And Job Satisfaction As Antecedents Of Career Withdrawal Cognition Among Teacher Interns. Journal of Research and Development in Education, 28, 30-236.

Lanner, M. (2010). Contributing Factors To Teacher Satisfaction For Jewish Day School Educators. UMI Dissertations Publishing: Yeshiva University.

Locklear, T. M. (2010). Factors Contributing To Teacher Retention In Georgia. Ph.D dissertation. The University of Alabama.

Marvel, J., Lyter, D. M., Peltola, P., Strizek, G. A. \& Morton, B. A. (2006). Teacher Attrition And Mobility: Results from the 2004-05 Teacher Follow-up Survey. NCES 2006.

Menlo, A. \& Poppleton, P. (1990). A Five Country Study Of The Work Perceptions Of Secondary School Teachers in England, the United States, Japan, Singapore and West Germany (1986-88). Comparative Education, 26 (2-3), 173-182.

Paulík, K. (2012). Job Satisfaction And Stress Among Teachers. EBSCOhost. The New Educational Review, 30(4), 138-149.

Poon, M. L. \& Lim, B. L. (1997). Kesan Efikasi Diri Terhadap Komitmen, Daya Usaha dan Prestasi Kerja di Kalangan Guru Sekolah. Jurnal Pendidikan, $18(2), 37-55$. Punanesvaran, A. Nadairaja. (2000). Hubungan Bebanan Kerja Dengan Tekanan Kerja Di Kalangan Guru Lelaki Dan Guru Wanita Di Sebuah Sekolah Rendah Di Kawasan Bandar. Universiti Kebangsaan Malaysia: Kajian Ilmiah.

Ramlee Mustapha. (2009). Job Satisfaction Among Vocational Teachers in Malaysia. International Journal for Educational Studies, 1(2), 169-186.

Ramlee Mustapha. (2011). Factors That Influence Job Satisfaction Among Vocational Teachers In Malaysia. Journal of Asian Vocational Education and Training, 4(1), 61-76.

Ramlee Mustapha (2013). Transforming Education Toward K-economy in Malaysia. International Journal for Educational Studies, 6(1), 1-16.

Schor, J. (2002, September 2). Why Americans Should Rest. New York Times, p.15.

Smithers, A., \& Robinson, P. (2003). Factors Affecting Teachers' Decisions To Leave The Profession. Research Report RR430. London: DfES.

Somech, A. \& Drach-Zahavy, A. (2000): Understanding Extra-Role Behavior In Schools: The Relationships Between Job Satisfaction, Sense Of Efficacy, And Teachers' Extra-Role Behavior. Teaching and Teacher Education, 16, 649-659.

Spector, P. E. (1997). Job Satisfaction: Application, Assessment, Causes, And Consequences. Thousand Oaks, CA: Sage Publications.

Tschannen-Moran, M. \& Hoy, A.W. (2001). Teacher Efficacy: Capturing An Elusive Construct. Teaching and Teacher Education. 17, $783-805$.

United States Department of Labor, Bureau of Labor Statistics. (2010). Occupational Outlook Handbook, 2010-2011 Edition. Indianapolis, IN: JIST Works, Inc.

Wong, K. H., \& Wong, T. R. (2009). The First Days Of School. Mountain View, CA: Harry K. Wong Publications, Inc.

Xiao, Z., \& Li, C. (2003). Woguo Jiaoshi Xuyao Yanjiu Shuping (Teachers' Needs in China). Journal of Hebei Normal University, $3,28-31$.

Zembylas, M., \& Papanastasiou, E. (2004). Job Satisfaction Among School Teachers in Cyprus. Journal of Educational Administration, 42(3), 357-374. 